\title{
Short communication: Cocoa husks can effectively replace soybean hulls in dairy sheep diets-Effects on milk production traits and hematological parameters
}

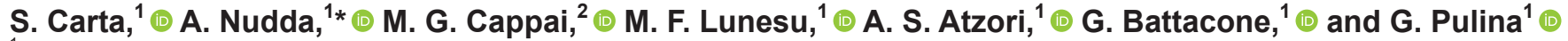 \\ ${ }^{1}$ Dipartimento di Agraria, Sezione di Scienze Zootecniche, Università degli studi di Sassari, 07100, Sassari, Italy \\ ${ }^{2}$ Dipartimento di Medicina Veterinaria, Università degli studi di Sassari, 07100, Sassari, Italy
}

\section{ABSTRACT}

The aim of this study was to test the effect of replacing soybean hulls with different doses of cocoa husk $(\mathrm{CH})$ on milk production traits and the hematological profile of dairy ewes. Twenty-four mid-lactating Sarda dairy ewes were allotted to 3 homogeneous experimental groups (8 animals per group divided into 4 pens). Each group received a total mixed ration as a basal diet and a supplement that differed among groups. The first group was supplemented with $100 \mathrm{~g}$ of soybean hulls/d per head (SBH group). In the second group, soybean hulls were replaced with $50 \mathrm{~g}$ of $\mathrm{CH} / \mathrm{d}$ (CH50 group). In the third group, soybean hulls were replaced with $100 \mathrm{~g}$ of $\mathrm{CH} / \mathrm{d}$ per head (CH100 group). The study lasted 8 wk, with 3 wk of adaptation and 5 wk for the experimental period. The replacement of soybean hulls with 50 and $100 \mathrm{~g}$ of $\mathrm{CH} / \mathrm{d}$ did not affect dry matter intake, milk production, and milk coagulation properties. Milk fat, protein, casein, and somatic cell count concentration and curd-firming time showed a significant interaction between treatment and sampling date. During the experiment, the somatic cell counts were lower in both the $\mathrm{CH} 50$ and $\mathrm{CH} 100$ groups than in the SBH group. Most of the hematological parameters were not affected by treatments except for basophiles, which were significantly higher in the SBH group than in the CH50 and CH100 groups. In conclusion, $\mathrm{CH}$ can be substituted for soybean hulls in the diet of dairy sheep without adverse effects on milk production or apparent negative effects on animal health conditions. Key words: by-product, cocoa husk, milk quality, dairy ewe, nutrition

Received September 6, 2019.

Accepted October 26, 2019.

*Corresponding author: anudda@uniss.it

\section{Short Communication}

Cocoa husk $(\mathbf{C H})$ is the principal by-product derived from Theobroma cacao L. (Sterculiaceae). It is obtained after the removal of the cocoa beans from the fruit and represents 70 to $75 \%$ of the fruit weight (Cruz et al., 2012). The processing of cocoa beans results in a large amount of waste, which has been estimated to be about 16 million tonnes of residual biomass every year (Vásquez et al., 2019). Cocoa by-products could possibly be used as a supplemental feed for animal ( $\mathrm{Lu}$ et al., 2018). However, this use is constrained by the presence in the cocoa by-products of a natural alkaloid, theobromine (3,7-dimethylxanthine), which has been found to be toxic to animals when ingested in large amounts (Adamafio, 2013). In vivo and in vitro studies on the effect of theobromine showed a reduction in adipogenesis and in the production of proinflammatory cytokines (Fuggetta et al., 2019). Moreover, effects on lipid and glucose metabolism (Camps-Bossacoma et al., 2019) and on oxidative stress (Azam et al., 2003) have been observed. The European Union has imposed a limit of $300 \mathrm{mg} / \mathrm{kg}$ on the content of theobromine in animal complete feeds (European Commission, 2002). Theobromine is rapidly absorbed and metabolized and is excreted partly as theobromine and its metabolites via urine. Data regarding the carryover of theobromine from feeds into milk are available only in humans (Aresta et al., 2005) and not in ruminants. Cocoa husk is a good source of fiber (38-44\%; Lecumberri et al., 2007) and contains variable amounts of NFC (17.5-47\%), protein (2.1-9.1\%), and lipids (0.6-4.7\%; Campos-Vega et al., 2018) and a good amount of phenolic compounds (4.6-6.9\% of gallic acid/100 g of DM; Lu et al., 2018) as catechin and epicatechin (Hernández-Hernández et al., 2019), which evidenced antioxidant (Lecumberri et al., 2007; Okiyama et al., 2017) and antiradical (Di Mattia et al., 2013; Bordiga et al., 2015) activities.

Soybean hulls are a well-known by-product widely used in ruminant feeding (Ipharraguerre and Clark, 2003); they are usually included in dairy sheep diet for 
their high amount of digestible fiber. The first objective of the present study was to evaluate the effect of including $\mathrm{CH}$ in the diet of dairy ewes on milk production. Considering the limit of $300 \mathrm{mg}$ of theobromine $/ \mathrm{kg}$ of feedstuffs imposed by EU legislation, as a secondary goal we also investigated the effect on hematological parameters and electrophoretic profile of blood serum protein fractions.

The experiment was approved by the Ethics Committee of the University of Sassari (no. 54584/2018). Twenty-four Sarda dairy ewes in middle lactation (DIM $=120 \pm 15 \mathrm{~d}$; parity $=3.1 \pm 1.2$; mean $\pm \mathrm{SD}$ ) were randomly allotted to 3 experimental groups ( 8 animals per group) homogeneous for (mean \pm SD) milk yield $(1.8 \pm 0.04 \mathrm{~kg} / \mathrm{d}$ per head), BW $(42.5 \pm 1.1 \mathrm{~kg})$, and BCS $(2.7 \pm 0.01)$. The study lasted 8 wk, with the first $3 \mathrm{wk}$ for adaptation. The ewes were machine milked at 0800 and $1600 \mathrm{~h}$, and individual milk yield was recorded weekly. Body condition score (1-to-5 point scale from lean to fat) and BW were monitored at the beginning and end of the experiment. Each group received 2.58 $\mathrm{kg}$ of TMR/d per head as the basal diet (Table 1) and a supplement of $100 \mathrm{~g}$ of soybean hulls $(\mathbf{S B H}) / \mathrm{d}$ per head (referred to as the SBH group), a supplement of $50 \mathrm{~g}$ of $\mathrm{CH} / \mathrm{d}$ per head (CH50 group), or a supplement of $100 \mathrm{~g}$ of $\mathrm{CH} / \mathrm{d}$ per head (CH100 group). The animals were allocated to 12 pens ( 2 ewes in each pen), and the TMR was offered 4 times per day. The supplements ( $\mathrm{SBH}$ and $\mathrm{CH}$ ) were administered individually during milking, mixed with beet pulp $(70 \mathrm{~g})$, to make them more palatable. The orts of TMR from each pen were weighed daily. Clean water was available ad libitum. Cocoa husks were collected from an Italian feed industry (Mignini and Petrini Spa, Patrignano di Assisi, PG, Italy); their chemical composition is reported in Table 1. The content of theobromine in the diets supplemented with $\mathrm{CH}$ (130 and $252 \mathrm{mg} / \mathrm{kg}$ for CH50 and $\mathrm{CH} 100$, respectively) was below the limits indicated by the European Commission (2002; Table 1). Feed samples were analyzed for DM $\left(105^{\circ} \mathrm{C}\right.$ for $\left.24 \mathrm{~h}\right)$, $\mathrm{CP}$, ether extract, and ash (AOAC International, 2000; methods 988.05, 920.39, and 942.05 respectively), NDF (using heat-stable $\alpha$-amylase; Mertens, 2002), ADF (AOAC, 1990; method 973.18), and ADL (Robertson and Van Soest, 1981). Nonfiber carbohydrates (\% of $\mathrm{DM})$ were calculated as $100-(\mathrm{NDF}+\mathrm{CP}+$ ash + ether extract). Protein fractions were determined as described by Licitra et al. (1996). All such parameters were expressed as percentage of DM. Fatty acid content in feed samples was analyzed as detailed by Correddu et al. (2016). Individual milk samples were collected weekly at morning and afternoon milking and analyzed separately for fat, protein, casein, lactose, and urea content (Milkoscan 6000, Foss Electric, Hillerød, Denmark) and for SCC (Fossomatic 360, Foss Electric). The value of each parameter was calculated as weighted average of the morning and afternoon data. Milk coagulation properties (rennet coagulation time, min; curd-firming time, min; curd firmness, $\mathrm{mm}$ ) were determined in morning samples using Formagraph (Foss Electric) as detailed by Manca et al. (2016).

Individual blood samples were collected via jugular venipuncture before the experimental period $\left(\mathrm{d} 0 ; \mathbf{T}_{\mathbf{0}}\right)$ and at the middle (d 28 from start; $\mathbf{T}_{1}$ ) and end ( $\mathrm{d} 56$ from start; $\mathbf{T}_{2}$ ) of the experimental period after the morning milking and $3 \mathrm{~h}$ after the removal of overnight TMR orts. Blood was taken in 2 distinct tubes for serum (Vacutainer Vacuette, Greiner Bio-One, Italia S.r.l, Italy, with clotting accelerator) and whole-blood (EDTA-K ${ }_{2}$ as anticoagulant) collection. Whole-blood samples were processed using an automatic cell counter instrument (BC-5000 hematology analyzer; Mindray, Shenzhen, China) to determine the following hematological parameters: white blood cell count, neutrophil granulocytes, lymphocytes, monocytes, eosinophil granulocytes, basophil granulocytes (BG), red blood cells, hemoglobin, hematocrit, mean corpuscular hemoglobin, mean corpuscular hemoglobin concentration, red cell distribution width (coefficient of variation and standard deviation), platelet, mean platelet volume, platelet distribution width, and plateletcrit. To define a common interpretation of leukocyte formula, absolute and relative values, recorded from each sample, were taken into account. Blood samples from tubes without anticoagulant were centrifuged at $1,500 \times g$ for $10 \mathrm{~min}$ at $4^{\circ} \mathrm{C}$ and were analyzed for serum protein fractions with semiautomatic electrophoresis equipment (Pretty; Interalab Srl, Rome, Italy) using the agarose gel as migration support. Electropherograms were scanned and acquired (PrettyScan software; Interlab Srl), and data were analyzed and interpreted by Elfolab software (Interalab Srl).

All data were analyzed as a completely randomized design with repeated measures using PROC MIXED of SAS version 9.2 (SAS Institute, 2008). The model included the fixed effects of diet, sampling, and diet $x$ sampling, and pen as random effect. For hematological parameters, $\mathrm{T}_{0}$ values were included as a covariate when significant.

The results showed that $\mathrm{SBH}$ and $\mathrm{CH}$ were completely eaten by each animal of all groups. The supplementation of $\mathrm{CH}$ did not decrease total DMI compared with SBH (Table 2) despite the higher amount of lignin present in this by-product (Table 1). This is probably linked to the presence of theobromine, which has been found to stimulate appetite in ruminants (Trout et al., 1978; Campos-Vega et al., 2018). Theobromine intake was equal to $308 \mathrm{mg}$ for CH50 (157 mg/kg of DMI) and 617 
mg for CH100 (308 mg/kg of DMI). Supplementation of $\mathrm{CH}$ did not influence the BCS and BW of ewes. To our knowledge, literature and data regarding lactating ruminants for comparison are scarce; however, BW was not affected in growing goats and pigs supplemented with cocoa by-products (Aregheore, 2002; Oddoye et al., 2010), whereas supplementation increased BW in broilers (Teguia et al., 2004) and rabbits (Hamzat et al., 2007).

The $\mathrm{CH}$ did not influence milk yield, milk composition, and milk coagulation properties compared with
SBH (Table 2). A significant effect of diet $\times$ sampling interaction on milk fat $(P=0.06)$, protein and casein $(P<0.001)$, and SCC $(P<0.05)$ has been observed, suggesting that $\mathrm{CH}$ may have a positive influence on quality of milk over time. In fact, milk fat increased in all groups as a consequence of milk concentration effect, but the CH100 group reached higher values of milk fat compared with the SBH group (Supplemental Figure S1, https://doi.org/10.3168/jds.2019-17550). A direct role of theobromine in milk fat synthesis could be considered because it has been found to affect lipid

Table 1. Chemical composition, fatty acid profile, total polyphenols, and nitrogen fractions of by-products and TMR

\begin{tabular}{|c|c|c|c|}
\hline Item & $\begin{array}{c}\text { Soybean } \\
\text { hulls }\end{array}$ & $\begin{array}{l}\text { Cocoa } \\
\text { husk }\end{array}$ & $\mathrm{TMR}^{1}$ \\
\hline \multicolumn{4}{|c|}{ Chemical composition (\% of DM unless otherwise noted) } \\
\hline $\mathrm{DM}(\%)$ & 89.34 & 89.52 & 88.59 \\
\hline $\mathrm{NDF}$ & 67.11 & 45.99 & 41.90 \\
\hline NFC & 16.45 & 23.08 & 37.20 \\
\hline ADL & 2.09 & 19.56 & 4.81 \\
\hline $\mathrm{CP}$ & 10.49 & 16.77 & 14.17 \\
\hline Ash & 5.06 & 8.60 & 5.82 \\
\hline Ether extract & 0.88 & 5.57 & 0.91 \\
\hline Theobromine $^{2}(\mathrm{mg} / \mathrm{kg}$ of DM$)$ & - & 6,850 & - \\
\hline Total polyphenol ( $\mathrm{g}$ of $\mathrm{GAE}^{3} / 100 \mathrm{~g}$ of $\left.\mathrm{DM}\right)$ & 0.22 & 3.36 & 1.21 \\
\hline $\mathrm{ME}^{4}(\mathrm{Mcal} / \mathrm{kg}$ of DM) & 2.46 & 2.19 & 2.40 \\
\hline ME supplied (Mcal/d) & - & - & 5.77 \\
\hline \multicolumn{4}{|l|}{ Major fatty acids ( $\mathrm{g} / 100 \mathrm{~g}$ of total fatty acids) } \\
\hline C12:0 & 0.08 & 0.09 & 0.14 \\
\hline C14:0 & 0.27 & 0.53 & 0.41 \\
\hline C16:0 & 16.72 & 24.24 & 17.43 \\
\hline C16:1 cis-7 & 0.11 & 0.00 & 0.20 \\
\hline C16:1 cis-9 & 0.50 & 0.79 & 0.22 \\
\hline C18:0 & 6.94 & 25.84 & 5.35 \\
\hline C18:1 cis-9 & 15.02 & 34.25 & 22.82 \\
\hline C18:1 cis-11 & 3.39 & 1.64 & 1.09 \\
\hline $\mathrm{C} 18: 2 \mathrm{n}-6$ & 40.84 & 8.44 & 41.94 \\
\hline C18:3n-3 & 10.20 & 0.68 & 5.21 \\
\hline C20:0 & 0.79 & 1.08 & 0.78 \\
\hline $\mathrm{C} 22: 0$ & 0.62 & 0.51 & 0.67 \\
\hline $\mathrm{C} 24: 0$ & 0.81 & 0.39 & 0.77 \\
\hline SFA & 28.95 & 53.59 & 27.35 \\
\hline UFA & 71.05 & 46.41 & 72.65 \\
\hline \multicolumn{4}{|l|}{ Nitrogen fraction ${ }^{5}(\%$ of $\mathrm{CP})$} \\
\hline $\mathrm{A}$ & 0.86 & 22.27 & 20.66 \\
\hline $\mathrm{B} 1$ & 11.51 & 3.10 & 3.67 \\
\hline B2 & 42.22 & 25.59 & 53.69 \\
\hline B3 & 29.83 & 4.67 & 11.71 \\
\hline $\mathrm{C}$ & 15.58 & 34.37 & 10.26 \\
\hline
\end{tabular}

${ }^{1}$ Composition: beet pulp $=37.98 \%$; soybean meal $=14.34 \%$; flaked corn $=14.11 \%$; dehydrated alfalfa $=8.53 \%$; barley $=5.81 \%$; rice $=4.65 \%$; straw $=4.57 \%$; hay $=3.33 \%$. The amount of TMR offered as fed was $2.58 \mathrm{~kg} / \mathrm{d}$ per ewe supplemented with $100 \mathrm{~g}$ of soybean (SBH group), $50 \mathrm{~g}$ of cocoa husks/d per head (group CH50), and $100 \mathrm{~g}$ of cocoa husks/d per head (CH100 group). Each by-product was mixed with $70 \mathrm{~g}$ of beet pulp (chemical composition of beet pulp: $\mathrm{DM}=90.46 \%$; $\mathrm{NDF}=46.89 \%$ of $\mathrm{DM} ; \mathrm{NFC}=36.97 \%$ of $\mathrm{DM}$; $\mathrm{ADL}=7.14 \%$ of $\mathrm{DM}$; $\mathrm{CP}=10.64 \%$ of $\mathrm{DM}$; ash $=4.88 \%$ of $\mathrm{DM}$; ether extract $=0.66 \%$ of $\mathrm{DM})$.

${ }^{2}$ Theobromine concentration: 130 and $253 \mathrm{mg} / \mathrm{kg}$ of DM in the offered diets for the CH50 and CH100 groups, respectively.

${ }^{3} \mathrm{GAE}=$ gallic acid equivalents.

${ }^{4}$ Calculated using the small ruminant nutrition model (Tedeschi et al., 2010).

${ }^{5} \mathrm{~A}=\mathrm{NPN}$; $\mathrm{B} 1$ = buffer soluble true protein; $\mathrm{B} 2$ = buffer insoluble protein - neutral detergent soluble protein; $\mathrm{B} 3=$ neutral detergent insoluble protein - acid detergent insoluble protein; $\mathrm{C}=$ acid detergent insoluble protein. 
metabolism in in vivo and in vitro models (Martín and Ramos, 2017; Jang et al., 2018). Milk protein content increased over time only in the CH100 and SBH groups, whereas it did not change in the CH50 group (Supplemental Figure S2, https://doi.org/10.3168/jds.2019 -17550). A role of this by-product and its components in protein metabolism could be hypothesized. Ali et al. (2014) observed an effect of supplementation with cocoa pod husk on BUN in beef cattle. The significant diet $\times$ time interaction in SCC evidenced lower variation over time in $\mathrm{CH}$ groups compared with the $\mathrm{SBH}$ group (Supplemental Figure S3, https://doi.org/10 .3168/jds.2019-17550).

The values of hematological parameters were within the physiological range for the sheep, except that BG in the SBH group exceeded the upper value of the reference range for this species (Table 3). Overall, hematological parameters were not affected by the diets, except BG that were significantly higher in the $\mathrm{SBH}$ group compared with the CH50 group (4.5-fold higher) and the CH100 group (3.5-fold higher). The literature reports that a potential effect on BG degranulation (and therefore disappearance from the bloodstream to reach target organs) can be induced by dietary polyphenols (Magrone et al., 2017; Pérot et al., 2017). However, it is also known that vasodilators such as histamine produced during inflammation can lead to the activa- tion of BG, with a consequent release of granules to contrasting antigen presence. Whether BG levels could reflect vasodilation associated with theobromine intake (EFSA, 2008) is unknown, and detailed knowledge about such effects is not yet available.

The electrophoresis of serum protein fractions showed to be within the reference values for healthy animals. No differences associated with the diet effect were observed. The $\beta_{2}$-globulin and $\gamma$-globulin fractions were significantly affected by sampling date (Table 3 ). The $\beta_{2}$-globulin average values (to which complement C3 protein and IgA belong) increased over time (sampling $\mathrm{T}_{0}$ vs. sampling $\mathrm{T}_{2}$ : 7.90 vs. $14.9 \mathrm{~g} / \mathrm{L} ; P<0.0001$ ), whereas $\gamma$-globulin fraction (accounting circulating antibodies) decreased over time (sampling $\mathrm{T}_{0}$ vs. sampling $\mathrm{T}_{2}$ : 19.4 vs. $15.7 \mathrm{~g} / \mathrm{L} ; P<0.0001$ ). Both fractions can therefore reflect the systemic inflammatory status and immunological activity of animals. It is encouraging to compare such values with those observed with other hematological parameters and the SCC found in milk. In fact, the overall evaluation can point to a more favorable productive condition of animals fed a diet containing $\mathrm{CH}$ along with desirable homeostasis and homeorhesis over time. In conclusion, feeding $\mathrm{CH}$ by-products to dairy ewes in replacement of SBH did not show negative effects on DMI, milk yield, and composition. The maximum level of theobromine included

Table 2. Effect of dietary supplementation of soybean hulls and 2 doses of cocoa husks on BW, BCS, milk yield, composition, and coagulation properties in Sarda dairy ewes

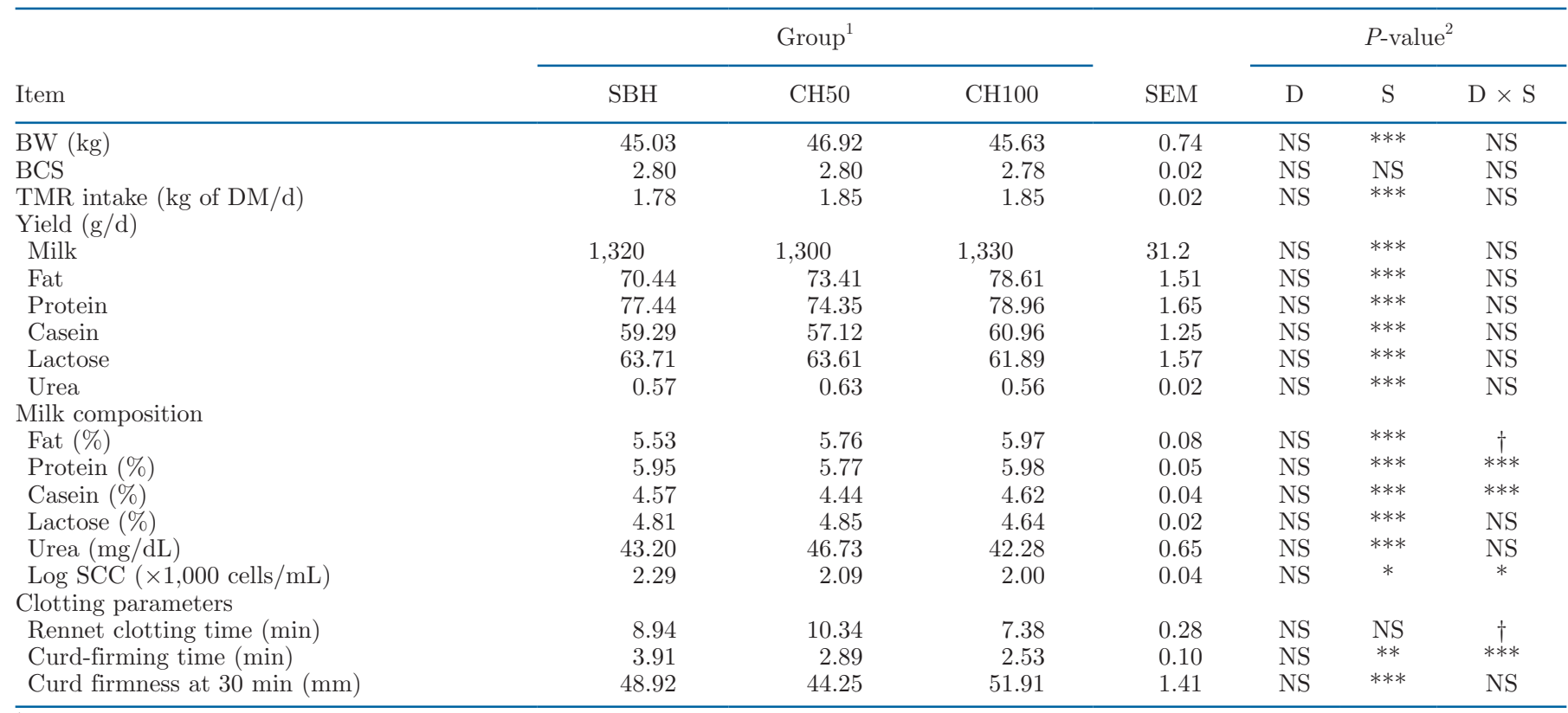

${ }^{1} \mathrm{SBH}=$ diet containing $100 \mathrm{~g}$ of soybean hulls/d per head; CH50 = diet supplemented with $50 \mathrm{~g}$ of cocoa husks/d per head; CH100 = diet supplemented with $100 \mathrm{~g}$ of cocoa husks/d per head.

${ }^{2} \mathrm{D}=$ effect of diet; $\mathrm{S}=$ effect of sampling date; $\mathrm{D} \times \mathrm{S}=$ effect of diet $\times$ sampling date interaction.

${ }^{*} P<0.05 ;{ }^{* *} P<0.01 ;{ }^{* * *} P<0.001 ; \dagger P<0.10 ;{ }^{\mathrm{NS}} P>0.10$. 
Table 3. Effect of dietary supplementation of soybean hulls and 2 doses of cocoa husks on hematological parameters and electrophoresis profile of serum protein fractions in dairy ewes

\begin{tabular}{|c|c|c|c|c|c|c|c|c|}
\hline Item $^{1}$ & $\begin{array}{l}\text { Reference } \\
\text { values }^{2}\end{array}$ & \multicolumn{3}{|c|}{ Group $^{3}$} & SEM & \multicolumn{3}{|c|}{$P$-value ${ }^{4}$} \\
\hline White blood cell count $\left(10^{9} / \mathrm{L}\right)$ & $5.10-15.80$ & 9.02 & 8.97 & 10.47 & 0.37 & NS & NS & NS \\
\hline Lymphocytes $\left(10^{9} / \mathrm{L}\right)$ & $2.01-7.80$ & $5.22^{\mathrm{b}}$ & $4.76^{\mathrm{b}}$ & $5.69^{\mathrm{a}}$ & 0.18 & $*$ & $\dagger$ & NS \\
\hline Monocytes $\left(10^{9} / \mathrm{L}\right)$ & $0.00-1.52$ & 0.53 & 0.50 & 0.57 & 0.04 & NS & $\dagger$ & NS \\
\hline Eosinophil granulocytes $\left(10^{9} / \mathrm{L}\right)$ & $0.00-1.08$ & 0.56 & 0.75 & 0.85 & 0.07 & NS & NS & NS \\
\hline Lymphocytes (\%) & $0.280-0.645$ & 0.41 & 0.36 & 0.38 & 0.01 & NS & NS & NS \\
\hline Monocytes (\%) & $0.000-0.143$ & 0.06 & 0.05 & 0.05 & 0.00 & NS & $*$ & NS \\
\hline Eosinophil granulocytes (\%) & $0.000-0.080$ & 0.05 & 0.06 & 0.06 & 0.00 & NS & NS & NS \\
\hline Basophil granulocytes (\%) & $0.000-0.015$ & $0.02^{\mathrm{a}}$ & $0.01^{\mathrm{b}}$ & $0.01^{\mathrm{b}}$ & 0.00 & $*$ & $\dagger$ & $*$ \\
\hline Red blood cell count $\left(10^{12} / \mathrm{L}\right)$ & $5.50-14.20$ & 8.24 & 8.86 & 8.84 & 0.15 & NS & NS & NS \\
\hline Hemoglobin $(\mathrm{g} / \mathrm{L})$ & $63-132$ & 88.66 & 91.37 & 94.12 & 1.39 & NS & $\dagger$ & NS \\
\hline Hematocrit $(\%)$ & $20-39$ & 19 & 19 & 20 & 0.23 & NS & NS & NS \\
\hline Mean platelet volume (fL) & $3.50-6.00$ & 4.20 & 4.46 & 4.32 & 0.05 & NS & $* * *$ & NS \\
\hline Platelet distribution width (fL) & $12.0-17.5$ & 15.13 & 15.19 & 15.17 & 0.04 & NS & NS & NS \\
\hline Plateletcrit (mL/L) & $0.50-4.20$ & 2.18 & 2.29 & 2.67 & 0.12 & NS & NS & $*$ \\
\hline \multicolumn{9}{|l|}{ Electrophoretic profile } \\
\hline Total protein $(\mathrm{g} / \mathrm{L})$ & $60.0-79.0$ & 70.0 & 70.1 & 70.1 & 1.12 & NS & NS & NS \\
\hline Albumin $(\mathrm{g} / \mathrm{L})$ & $24.0-30.0$ & 28.9 & 29.1 & 29.5 & 0.16 & NS & NS & NS \\
\hline$\alpha$-Globulins (g/L) & $3.0-6.0$ & 4.53 & 4.28 & 4.05 & 0.97 & NS & NS & NS \\
\hline$\beta_{1}$-Globulins $(\mathrm{g} / \mathrm{L})$ & $7.0-12.0$ & 8.29 & 8.50 & 8.39 & 0.99 & NS & NS & NS \\
\hline$\beta_{2}$-Globulins $(\mathrm{g} / \mathrm{L})$ & $4.0-14.0$ & 12.2 & 10.8 & 11.2 & 5.52 & NS & $* * *$ & NS \\
\hline$\gamma$-Globulins $(\mathrm{g} / \mathrm{L})$ & $9.0-33.0$ & 17.9 & 17.4 & 16.9 & 3.03 & NS & $* * *$ & NS \\
\hline Albumin:globulin ratio & $0.40-0.80$ & 0.71 & 0.72 & 0.73 & 0.11 & NS & $\dagger$ & NS \\
\hline
\end{tabular}

$\overline{\mathrm{a}, \mathrm{b}} \mathrm{Means}$ within a row with different superscripts are statistically different $(P<0.05)$.

${ }^{1} \mathrm{MCH}=$ mean corpuscular hemoglobin; $\mathrm{MCHC}=$ mean corpuscular hemoglobin concentration; RDW-CV = red cell distribution width-coefficient of variation; RDW-SD = red cell distribution width-standard deviation.

${ }^{2}$ From Kaneko et al. (2008).

${ }^{3} \mathrm{SBH}=$ diet containing $100 \mathrm{~g}$ of soybean hulls/d per head; CH50 = diet supplemented with $50 \mathrm{~g}$ of cocoa husks/d per head; CH100 = diet supplemented with $100 \mathrm{~g}$ of cocoa husks/d per head.

${ }^{4} \mathrm{D}=$ effect of diet; $\mathrm{S}=$ effect of sampling date; $\mathrm{D} \times \mathrm{S}=$ effect of diet $\times$ sampling date interaction.

${ }^{*} P<0.05 ;{ }^{* *} P<0.01$; *** $P<0.001 ; \dagger P<0.10 ;{ }^{\text {NS }} P>0.10$.

in the CH100 group, which corresponded to $617 \mathrm{mg} / \mathrm{d}$, did not indicate apparent adverse effects on the health status of animals.

\section{ACKNOWLEDGMENTS}

The authors gratefully acknowledge Mignini-Petrini S.p.a. (Perugia, Italy) for financial support to this research. There is no conflict of interest for any of the authors.

\section{REFERENCES}

Adamafio, N. A. 2013. Theobromine toxicity and remediation of cocoa by-products: An overview. J. Biol. Sci. 13:570-576. https://doi .org/10.3923/jbs.2013.570.576.

Ali, H. M., G. Alam, J. A. Syamsu, S. Salengke, and M. A. Asja. 2014. Average daily gain, AST and blood nitrogen urea (BUN) responses of Bali beef on cocoa waste extract supplement. J. Adv. Agric. Technol. 1:5-9. https://doi.org/10.12720/joaat.1.1.5-9.

AOAC. 1990. Official Methods of Analysis. AOAC, Arlington, VA.

AOAC International. 2000. Official Methods of Analysis. 17th ed. AOAC Int., Arlington, VA.

Aregheore, E. M. 2002. Chemical evaluation and digestibility of cocoa (Theobroma cacao) byproducts fed to goats. Trop. Anim. Health Prod. 34:339-348. https://doi.org/10.1023/A:1015638903740.

Aresta, A., F. Palmisano, and C. G. Zambonin. 2005. Simultaneous determination of caffeine, theobromine, theophylline, paraxanthine and nicotine in human milk by liquid chromatography with diode array UV detection. Food Chem. 93:177-181. https://doi.org/10 .1016/j.foodchem.2004.11.013.

Azam, S., N. Hadi, N. U. Khan, and S. M. Hadi. 2003. Antioxidant and prooxidant properties of caffeine, theobromine and xanthine. Med. Sci. Monit. 9:BR325-BR330.

Bordiga, M., M. Locatelli, F. Travaglia, J. D. Coïsson, G. Mazza, and M. Arlorio. 2015. Evaluation of the effect of processing on cocoa polyphenols: Antiradical activity, anthocyanins and procyanidins profiling from raw beans to chocolate. Int. J. Food Sci. Technol. 50:840-848. https://doi.org/10.1111/ijfs.12760.

Campos-Vega, R., K. H. Nieto-Figueroa, and B. D. Oomah. 2018. Cocoa (Theobroma cacao L.) pod husk: Renewable source of bioac- 
tive compounds. Trends Food Sci. Technol. 81:172-184. https:// doi.org/10.1016/j.tifs.2018.09.022.

Camps-Bossacoma, M., M. Garcia-Aloy, S. Saldaña-Ruiz, T. Cambras, R. González-Domínguez, À. Franch, F. J. Pérez-Cano, C. Andres-Lacueva, and M. Castell. 2019. Role of theobromine in cocoa's metabolic properties in healthy rats. J. Agric. Food Chem. 67:3605-3614. https://doi.org/10.1021/acs.jafc.8b07248.

Correddu, F., G. Gaspa, G. Pulina, and A. Nudda. 2016. Grape seed and linseed, alone and in combination, enhance unsaturated fatty acids in the milk of Sarda dairy sheep. J. Dairy Sci. 99:1725-1735. https://doi.org/10.3168/jds.2015-10108.

Cruz, G., M. Pirilä, M. Huuhtanen, L. Carrión, E. Alvarenga, and R. L. Keiski. 2012. Production of activated carbon from cocoa (Theobroma cacao) pod husk. J. Civil Environ. Eng. 2:1-6. https://doi .org/10.4172/2165-784X.1000109.

Di Mattia, C., M. Martuscelli, G. Sacchetti, I. Scheirlinck, B. Beheydt, D. Mastrocola, and P. Pittia. 2013. Effect of fermentation and drying on procyanidins, antiradical activity and reducing properties of cocoa beans. Food Bioprocess Technol. 6:3420-3432. https://doi .org/10.1007/s11947-012-1028-x.

European Commission. 2002. Directive 2002/32/EC of the European Parliament and of the Council of 7 May 2002 on undesirable substances in animal feed. Off. J. Eur. Comm. 140:10-21.

European Food Safety Authority. 2008. Theobromine as undesirable substances in animal feed. Scientific opinion of the Panel on Contaminants in the Food Chain. EFSA J. 725:1-66.

Fuggetta, M. P., M. Zonfrillo, C. Villivà, E. Bonmassar, and G. Ravagnan. 2019. Inflammatory microenvironment and adipogenic differentiation in obesity: The inhibitory effect of theobromine in a model of human obesity in vitro. Mediators Inflamm. 2019:1515621. https://doi.org/10.1155/2019/1515621.

Hamzat, R. A., O. O. Adejinmi, B. B. Babatunde, and M. O. Adejumo. 2007. Evaluation of cocoa shell as a feed ingredient for rabbits. Pages 583-584 in Proc. African Crop Sci. Conf., El-Minia, Egypt. African Crop Science Society, El-Minia, Egypt.

Hernández-Hernández, C., A. Morales-Sillero, J. Fernández-Bolaños, A. Bermúdez-Oria, A. A. Morales, and G. Rodríguez-Gutiérrez. 2019. Cocoa bean husk: Industrial source of antioxidant phenolic extract. J. Sci. Food Agric. 99:325-333. https://doi.org/10.1002/ jsfa.9191.

Ipharraguerre, I. R., and J. H. Clark. 2003. Soy hulls as an alternative feed for lactating dairy cows: A review. J. Dairy Sci. 86:1052-1073. https://doi.org/10.3168/jds.S0022-0302(03)73689-3.

Jang, M. H., N. H. Kang, S. Mukherjee, and J. W. Yun. 2018. Theobromine, a methylxanthine in cocoa bean, stimulates thermogenesis by inducing white fat browning and activating brown adipocytes. Biotechnol. Bioprocess Eng. 23:617-626. https://doi.org/10 .1007/s12257-018-0434-y.

Kaneko, J. J., J. W. Harvey, and M. L. Bruss. 2008. Clinical Biochemistry of Domestic Animals. 6th ed. Academic Press, Cambridge, MA.

Lecumberri, E., R. Mateos, M. Izquierdo-Pulido, P. Rupérez, L. Goya, and L. Bravo. 2007. Dietary fibre composition, antioxidant capacity and physico-chemical properties of a fibre-rich product from cocoa (Theobroma cacao L.). Food Chem. 104:948-954. https://doi .org/10.1016/j.foodchem.2006.12.054.

Licitra, G., T. M. Hernandez, and P. J. Van Soest. 1996. Standardization of procedures for nitrogen fractionation of ruminant feeds. Anim. Feed Sci. Technol. 57:347-358. https://doi.org/10.1016/ 0377-8401(95)00837-3.

Lu, F., J. Rodriguez-Garcia, I. Van Damme, N. Westwood, L. Shaw, J. S. Robinson, G. Warren, A. Chatzifragkou, S. McQueen Mason, L. Gomez, L. Faas, K. Balcombe, C. Srinivasan, F. Picchioni, P. Hadley, and D. Charalampopoulos. 2018. Valorisation strategies for cocoa pod husk and its fractions. Curr. Opin. Green Sustain. Chem. 14:80-88. https://doi.org/10.1016/j.cogsc.2018.07.007.

Magrone, T., M. A. Russo, and E. Jirillo. 2017. Cocoa and dark chocolate polyphenols: From biology to clinical applications. Front. Immunol. 8:677. https://doi.org/10.3389/fimmu.2017.00677.

Manca, M. G., J. Serdino, G. Gaspa, P. Urgeghe, I. Ibba, M. Contu, P. Fresi, and N. P. P. Macciotta. 2016. Derivation of multivariate indices of milk composition, coagulation properties, and individual cheese yield in dairy sheep. J. Dairy Sci. 99:4547-4557. https://doi .org/10.3168/jds.2015-10589.

Martín, M. Á., and S. Ramos. 2017. Health beneficial effects of cocoa phenolic compounds: A mini-review. Curr. Opin. Food Sci. 14:20-25. https://doi.org/10.1016/j.cofs.2016.12.002.

Mertens, D. R. 2002. Gravimetric determination of amylase-treated neutral detergent fiber in feeds with refluxing beakers or crucibles: Collaborative study. J. AOAC Int. 85:1217-1240.

Oddoye, E. O. K., S. W. A. Rhule, K. Agyente-Badu, V. Anchirinah, and F. O. Ansah. 2010. Fresh cocoa pod husk as an ingredient in the diets of growing pigs. Sci. Res. Essays 5:1141-1144.

Okiyama, D. C., S. L. Navarro, and C. E. Rodrigues. 2017. Cocoa shell and its compounds: Applications in the food industry. Trends Food Sci. Technol. 63:103-112. https://doi.org/10.1016/j.tifs.2017 .03 .007 .

Pérot, M., R. Lupi, S. Guyot, C. Delayre-Orthez, P. Gadonna-Widehem, J. Y. Thébaudin, M. Bodinier, and C. Larré. 2017. Polyphenol interactions mitigate the immunogenicity and allergenicity of gliadins. J. Agric. Food Chem. 65:6442-6451. https://doi.org/10 .1021/acs.jafc.6b05371.

Robertson, J. B., and P. J. Van Soest. 1981. The detergent system of analysis and its application to human foods. Page 123 in The Analysis of Dietary Fiber in Food. W. P. T. James and O. Theander, ed. Marcel Dekker, New York, NY.

SAS Institute. 2008. User's Guide: Statistics. Version 9.2. SAS Institute Inc., Cary, NC.

Tedeschi, L. O., A. Cannas, and D. G. Fox. 2010. A nutrition mathematical model to account for dietary supply and requirements of energy and other nutrients for domesticated small ruminants: The development and evaluation of the Small Ruminant Nutrition System. Small Rumin. Res. 89:174-184. https://doi.org/10.1016/j .smallrumres.2009.12.041.

Teguia, A., H. N. L. Endeley, and A. C. Beynen. 2004. Broiler performance upon dietary substitution of cocoa husks for maize. Int. J Poult. Sci. 3:779-782. https://doi.org/10.3923/ijps.2004.779.782.

Trout, G. A., B. L. Zoumas, and S. M. Tarka. 1978. Method of stimulating appetite in ruminants and ruminant feed containing appetite stimulant. US Pat. No. 4,070,487.

Vásquez, Z. S., D. P. de Carvalho Neto, G. V. M. Pereira, L. P. S. Vandenberghe, P. Z. de Oliveira, P. B. Tiburcio, H. L. G. Rogez, A. Góes Neto, and C. R. Soccol. 2019. Biotechnological approaches for cocoa waste management: A review. Waste Manag. 90:72-83. https://doi.org/10.1016/j.wasman.2019.04.030.

\section{ORCIDS}

S. Carta (ำ https://orcid.org/0000-0002-5778-2627

A. Nudda ( ) https://orcid.org/0000-0002-9807-0626

M. G. Cappai (๑) https://orcid.org/0000-0001-8863-9834

M. F. Lunesu (®) https://orcid.org/0000-0002-4260-6364

A. S. Atzori @ https://orcid.org/0000-0001-5083-241X

G. Battacone $\odot$ https://orcid.org/0000-0003-2146-6937

G. Pulina (ํ) https://orcid.org/0000-0001-5579-0677 